\title{
MORPHOTECTONIC ANALYSIS OF KOZANI BASIN (WESTERN MACEDONIA, GREECE)
}

\author{
Simou E. ${ }^{1}$, Karagkouni V. ${ }^{1}$, Papantoniou G. ${ }^{1}$, Papanikolaou D. ${ }^{1}$ and Nomikou \\ P.
}

${ }^{I}$ National and Kapodistrian University of Athens, Faculty of Geology and Geoenvironment, Department of Dynamic, Tectonic and Applied Geology, erinisim@gmail.com, vasilikikaragouni@gmail.com,gapap@live.com,dpapan@geol.uoa.gr,evinom@geol.uoa.gr,

\begin{abstract}
Kozani Basin is located in northern-central Greece and constitutes the southernmost of the Plio-Pleistocene basins of western Macedonia. Quantitative and qualitative analysis of morphological slope values, as well as the analysis of the drainage pattern in Kozani Basin confirms that the current topographic relief reflects intense neotectonic activity. Synthetic Morphotectonic Map of the under study area was carried out by means of the combined use of: (a) Digital Elevation Model (DEM), (b) Slope Distribution Map, (c) Morphological Slope Map and (d) Drainage Pattern Map. The composition of the digital modelling in conjunction with the regional geological setting, allows the identification of the main morphological discontinuities and lineaments that result from morphotectonic interpretation. The high morphological slope values indicate well-defined morphotectonic features, which mainly trend NE - SW and, secondarily, NW - SE. Distinct tectonic structures are mostly recognized in the SE margin of Kozani Basin, which is characterized by intense topographic relief. The main large-scale tectonic structure trends NE - SW and corresponds to the major Aliakmonas marginal fault zone that bounds the Kozani basin to the south. On the other hand, the NW margin's features are indiscernible; thus, the criteria for their recognition are based on the existence of the river terraces, which reflect the tectonic control. The results of our studies are presented on the Morphotectonic Map, which is followed by our 3D model of Kozani Basin.
\end{abstract}

Key words: tectonic geomorphology, Aliakmonas fault zone, morphotectonic structures.

\section{Пєрí $\eta \psi \eta$}

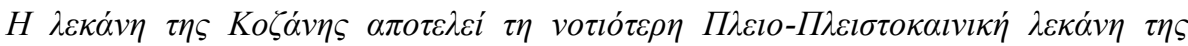

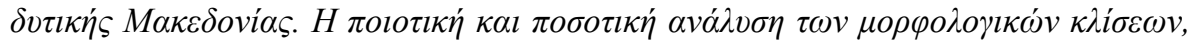

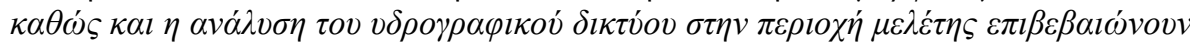

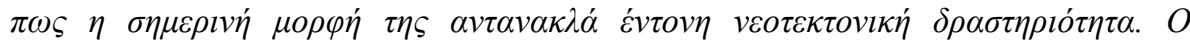

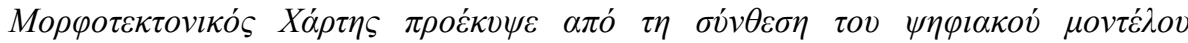

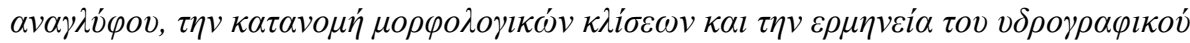

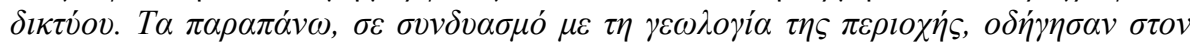

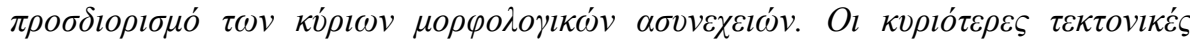

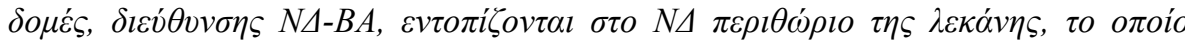

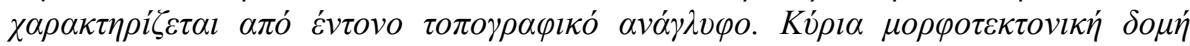

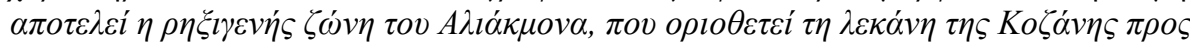

XLVII. No $2-657$ 


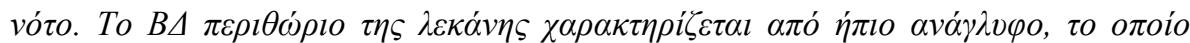

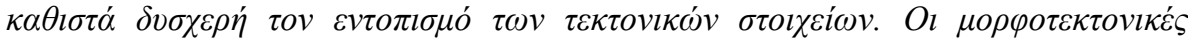

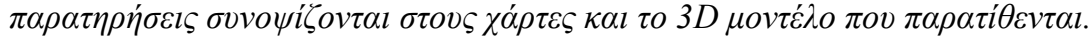

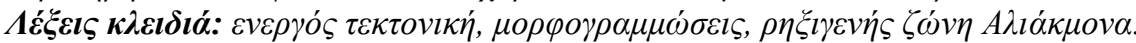

\section{Introduction}

Kozani basin is geographically situated in northern-central Greece and constitutes the southernmost of the Plio-Pleistocene basins of western Macedonia (Parcharidis et al, 2001). The above inland basin, which trends NE - SW, is bounded by Askion Mt. and Vourinos Mt. to NW and SE respectively, Kamvounia Mts. to the south and Pieria Mts. to E-SE (Figure 1).

320000 350000

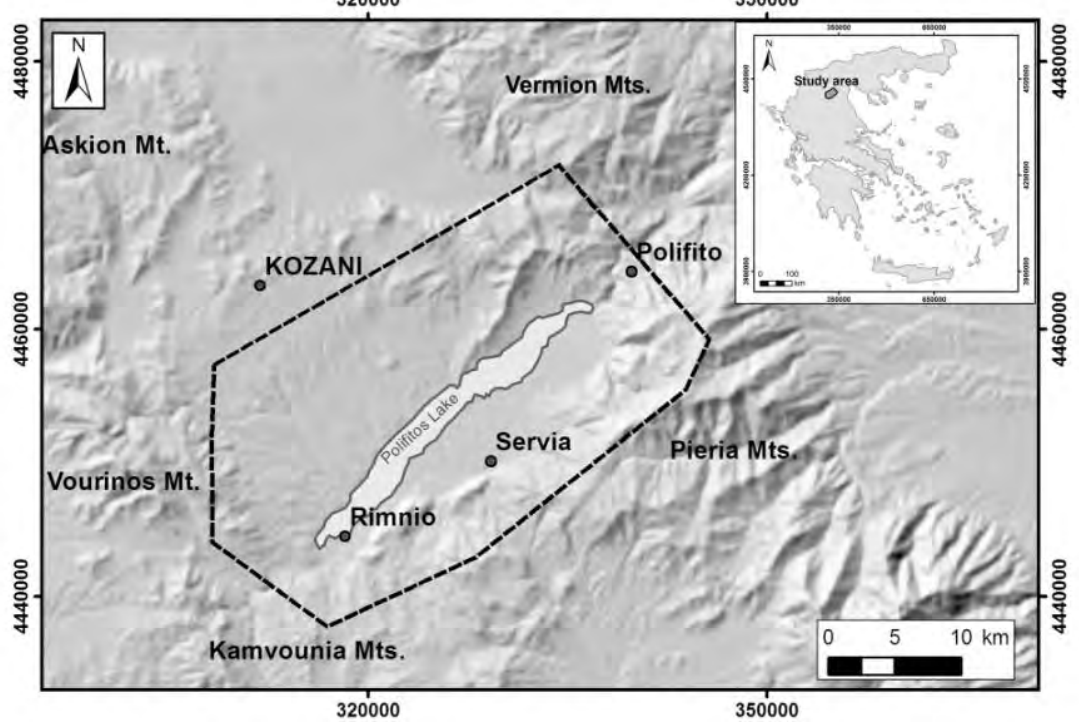

Figure 1 - Geographical location of the Kozani basin (GGRS87). The dashed line outlines the study area.

Mountrakis et al. (1998), have studied the several successive tectonic events related to the development of the Kozani basin. Knowing the resulting tectonic data, which correspond to our project area, we attempted to discriminate the significant tectonic structures of Kozani basin by mainly assessing the regional geomorphological and geological conditions. More specifically, the aim of the project has been the fault recognition by applying morphostructural analysis, which was based on the qualitative and quantitative interpretation of the topography, the slope distribution and the drainage pattern development in the study area.

\section{Methodology}

Since there was a large number of data in different formats (raster and vector) the GIS methodology has been the most suitable for our analysis. ArcGIS 10 package has been used for the data processing and the map composition and Surfer V. 10 / Rockware for the final 3D modelling. The construction of the Slope Distribution Map, the Morphological Map and the Drainage Pattern Map was based on: (i) the determination and classification of the morphological slope values, (ii) the evaluation of the morphological discontinuities and (iii) the drainage pattern interpretation, which were carried out in order to identify the neotectonic structures and their possible morphological expression. The aim of the above procedure was the construction of the Morphotectonic Sketch Map, which presents the major tectonic structures of the project area.

$\underline{\text { XLVII. No } 2-658}$ 


\section{Geological Setting}

\subsection{Geotectonic Structure}

The alpine basement of the Kozani neotectonic basin (Figure 1) is geotectonically located in the medial tectonometamorphic zone (Papanikolaou, 1984; Papanikolaou, 1986; Papanikolaou et al., 2004), also known as Pelagonian geotectonic unit (Mountrakis, 1985). The geological formations that can be observed in the wider Kozani area are the following (Neotectonic Map of Greece, Kozani Sheet, Scale: 1:100 000, Mountrakis et al. 1999):

- Alpine Formations (Figure 2): (a) Eastern Greece Unit formations. They outcrop at the SE and WNW part of the study area. They are Mesozoic carbonate formations, which mainly consist of Triassic-Jurassic crystalline limestones and dolomites, (b) Flambouro Unit formations, which mainly consist of upper Palaeozoic gneisses and amphibolites. They outcrop at the SW part of the study area and constitute the basement of the Pelagonian zone (Papanikolaou, 1986), and (c) Vourinos Ophiolite Complex. The ophiolite formations consist of basaltic lavas, dacites, diorites, gabbro and, mainly, peridotites (Mavridis \& Kelepertzis, 1993).

- Post-alpine Formations (Figure 2). They are Holocene deposits (alluvial deposits and scree material) and thick sequences of Plio-Pleistocene sediments, composed by fluvial and lacustrine coarse-grained, unconsolidated clastic material (loose conglomerates, clays, sands and sandstones).

\subsection{Tectonics}

Previous studies and structural analyses that were carried out in western Macedonia (Pavlides S., 1985; Pavlides et al., 1987; Mountrakis et al., 1993; Mountrakis et al., 1998; Burchfiel et al., 2008) determined the successive tectonic events, which have taken place during the Tertiary evolution. In Early Oligocene, the regional extensional stress field formed NNW-SSE trending normal faults. Middle-Late Miocene was characterised by two compressional deformation stages; (i) an ENEWSW compressional event responsible for NNW-SSE trending reverse faults, as well as dextral strike-slip transfer faults of E-W to NE-NW direction and (ii) a NNE-SSW compressional stress field, which activated E-W trending reverse faults. A Late Miocene-Pliocene subsequent extensional deformation event, expressed by NNW-SSE trending normal faults, started forming the Kozani - Ptolemais basin. The extensional stress field remained active during Early-Middle Pleistocene and formed the existing half-graben structure controlled by NE-SW to ENE-WSW basin's marginal faults, which are related to steep scarps, drainage asymmetries and other morphotectonic features which were also interpreted on the following morphotectonic analysis.

\subsection{Geomorphology}

\subsubsection{Drainage Pattern Analysis}

The drainage pattern in Kozani basin is characterized by intense asymmetry, especially between the NW and SE margin. The drainage disorders reveal the tectonic structures that have significant influence on the current topographic relief, as presented on the Synthetic Drainage Pattern Map (Figure 2). The project area is mainly characterized by parallel drainage pattern (Figure 2 - area 1). The streams are straight, trending NW-SE to NNW-SSE in both margins, with very few tributaries. Flow is accumulated towards SE and NW at the NW and SE margin of the basin respectively. Parallel drainage pattern indicates the smooth to moderate steep slopes (Howard, 1967), which are identified at the northwest part of the study area (Figure 2) and consist of unconsolidated postalpine formations; lacustrine deposits and mostly sands, clays, marls, sandstones and conglomerates, which comprise easily erodible material. The elongated streams $(\sim 10-15 \mathrm{~km}$ in length) can be explained by the tilting of the NW part of the basin towards N (Goldsworthy \& Jackson, 2000), as a result of the major active NE-SW trending tectonic structure, which is known 
as the Aliakmonas fault zone. Tilting of fault blocks can also be interpreted by local asymmetries of the drainage pattern which develops on the alpine basement (Mesozoic carbonate formations of Eastern Greece unit) in area 3 (Figure 2). Flow in the few existing tributaries might be related to the differential erosion rates, which depend on the geological background.

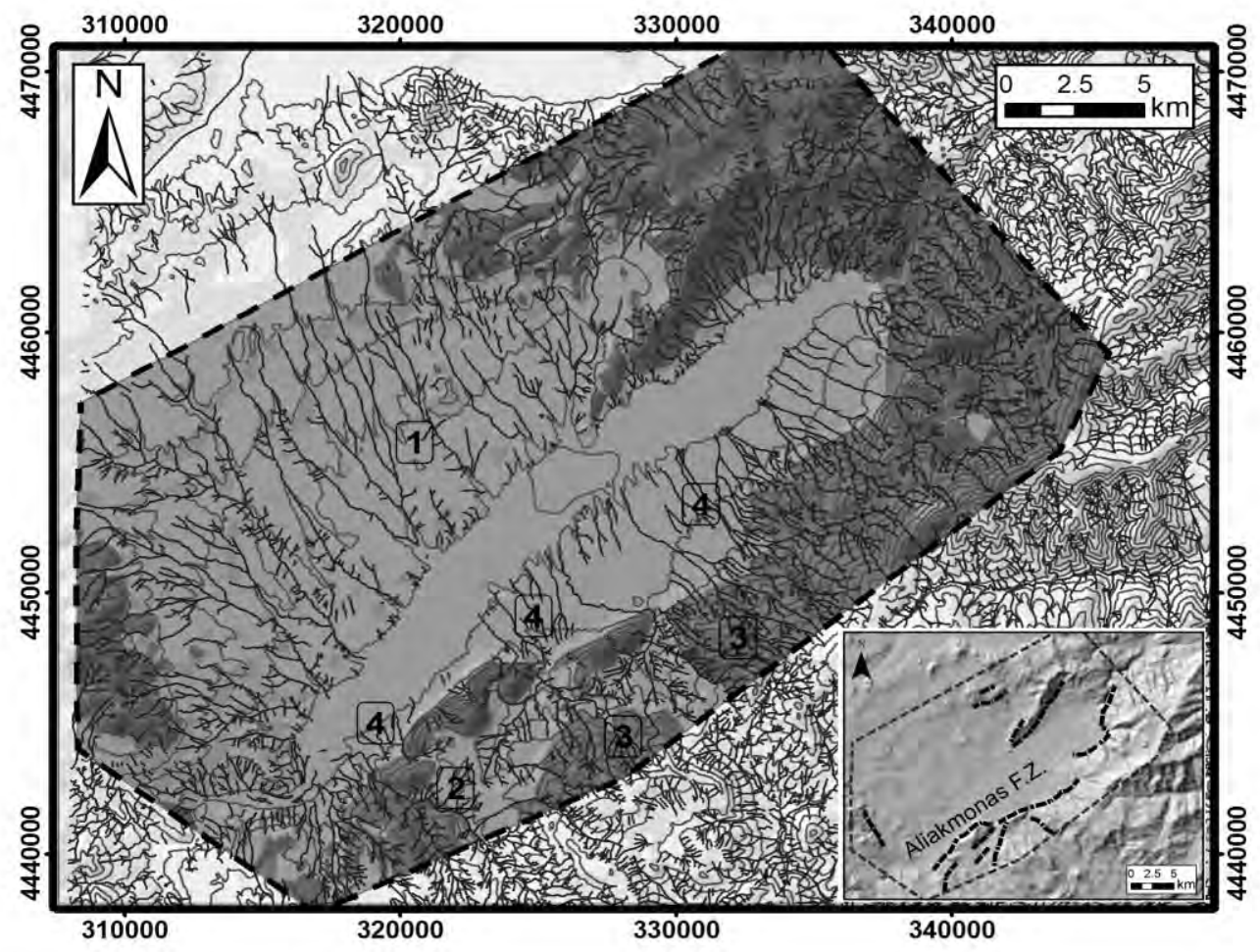

Figure 2 - Synthetic Drainage Pattern Map (GGRS87). Dark and light grey colours indicate the alpine basement and the post-alpine sediments respectively (after Mavridis \&

Kelepertzis, 1993; Mountrakis et al., 1999). The picture on the right bottom corner presents the morphotectonic features that can be interpreted by the local drainage asymmetries

(numbers are explained in the text).

Rectangular drainage pattern develops locally in the SE margin of the basin (area 2 of Figure 2). The tectonic activity is controlled by the predominant joint systems, which characterize the alpine basements formations.

Drainage asymmetries in the SE margin of the Kozani basin may also indicate the fault segmentation of the main large scale Aliakmonas fault zone (Goldsworthy \& Jackson, 2000). The drainage flows from the footwall (SE margin - Alpine basement) to the hanging wall (NW margin - Post-alpine sediments) at the lower topographic areas, which seem to be related to the ends of the fault segments (Figure 2 - areas 4). The small catchments are more related to the lithology rather than the tectonic setting, as they indicate the karstification of the Mesozoic carbonate bedrock at the southeast part of the study area.

Drainage pattern analysis in combination with the following morphological slope values has contributed in the morphotectonic interpretation of the Kozani basin. 


\subsubsection{Slope Distribution and Morphological Slope Analysis}

The geomorphological signatures that have affected topography allow the configuration of the active faulting in the study area. Topographic map and slope distribution map processing contributed to the distinction of two main areas in the Kozani basin: the NW margin, characterized by smooth topographic relief and the SE margin, which is characterized by steeper slopes. More specifically, the project area was analysed with regard to the slope distribution. The results of the slope values analysis are presented on the Slope distribution map (Figure 3) and the Morphological slope map (Figure 4).

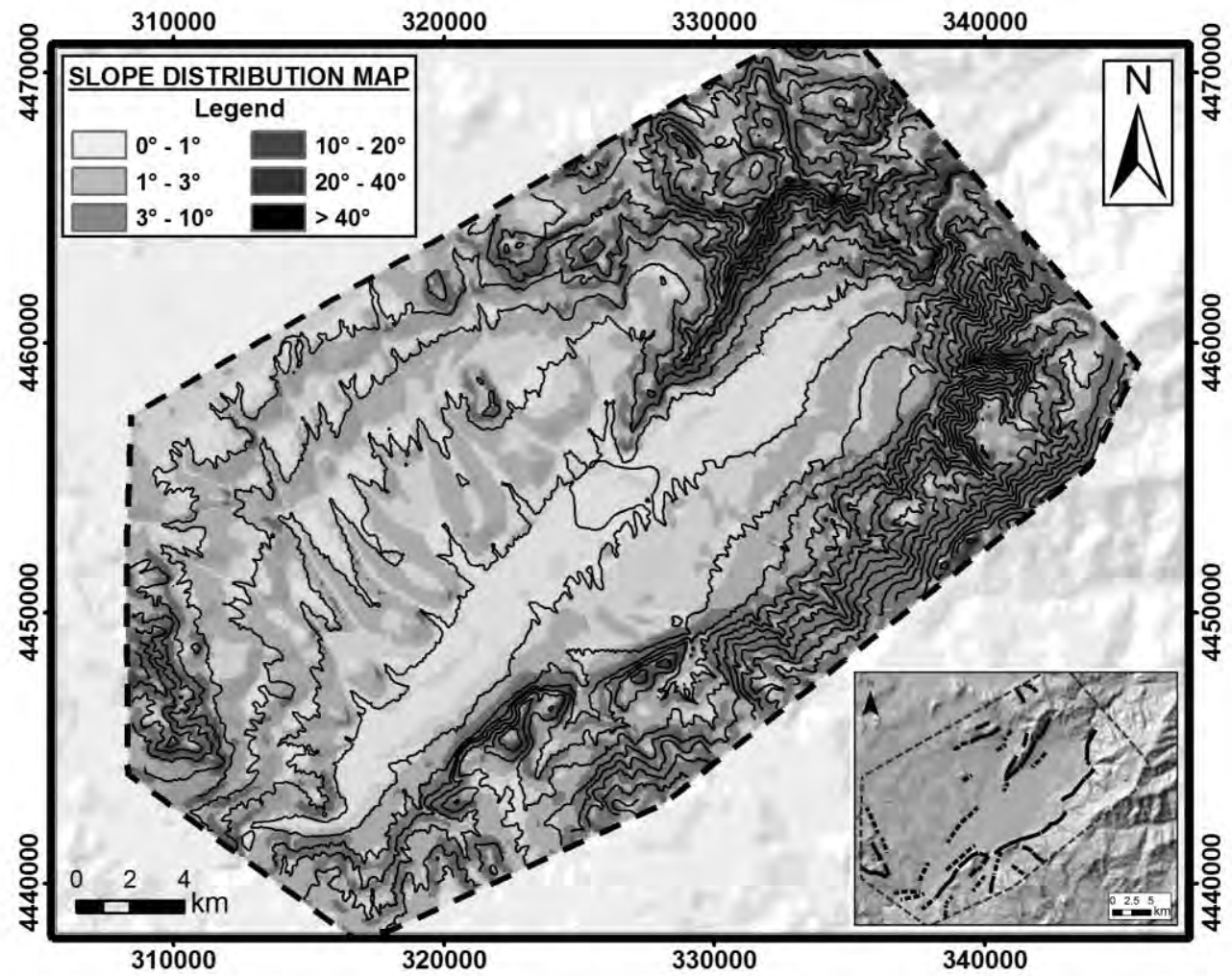

Figure 3 -Slope Distribution Map of Kozani basin (GGRS87). The slope values are in degrees. The picture on the right bottom corner presents the tectonic features that can be interpreted after the classification of the slope values.

On the slope distribution map, the slope values are distinguished in 6 classes: (i) flat areas of $0^{\circ}-1^{\circ}$ (basinal area), (ii) areas of mean morphological slope values of $1^{\circ}-3^{\circ}$, (iii) areas of $3^{\circ}-10^{\circ}$, (iv) areas of $10^{\circ}-20^{\circ}$, (v) areas of $20^{\circ}-40^{\circ}$ and (vi) steeper areas of $>40^{\circ}$. This classification aims to indicate areas characterized by abrupt change of slope values, which reflect the position of active tectonic structures (S and SE part of the project area - Figure 3). On the contrary, the areas of negligible change of the slope values, suggest plain areas on post-alpine formations related to river terraces or basinal areas (NW part of the project area - Figure 3).

The morphological slope map (Figure 4) reaffirms the above results. It constitutes a quantitative map, which aims to present not only the slope values but the direction of the slopes as well, indicating thereby the overall shape of the basin. The slope discontinuities (Figure 4) that can be distinguished are related to the active tectonic structures of Kozani basin. 


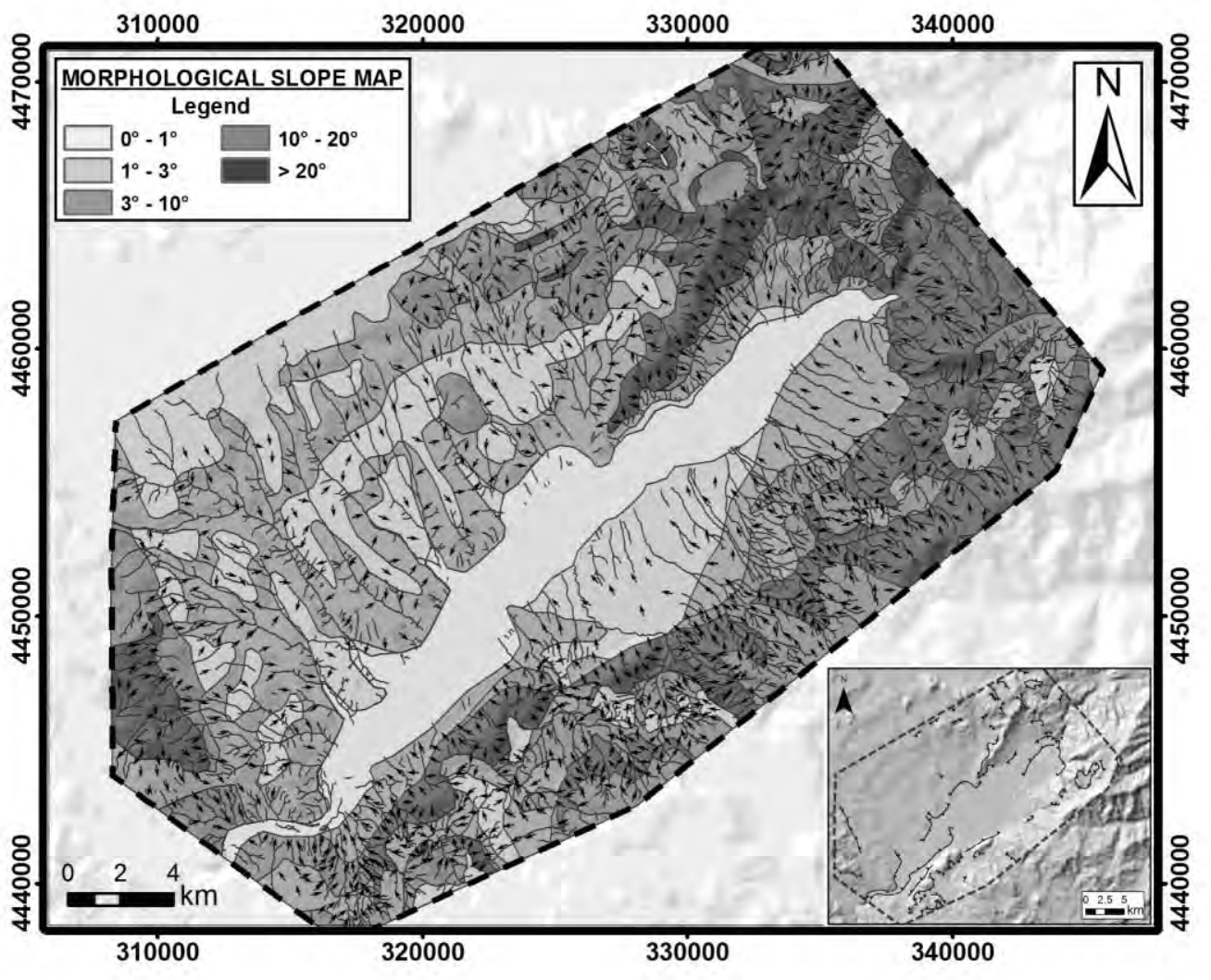

Figure 4 - Morphological Slope Map of Kozani basin (GGRS87), presenting the slope values classification (in degrees). The arrows indicate the dip direction of the slopes. The picture on the bottom right corner illustrates the slope discontinuities.

\section{Morphotectonic Interpretation - Results}

The morphotectonic interpretation, accomplished by the compilation of the previously presented maps, has led to the construction of the Morphotectonic sketch map (Figure 5), which illustrates the major morphotectonic features of the project area.

The overall morphology of Kozani basin seems to be controlled by the large-scale faults, which can be defined by the abrupt alternations of the morphological slope values (Figure 4) and the local drainage asymmetries (Figure 2). The defined tectonic structures of the basin, as it can be concluded by the statistical analysis (Figure 5 - rose plots), are developed primarily in a NE - SW direction and, secondarily, in a NW - SE one, following the slope direction distribution. It is remarkable that the most significant NE - SW trending faults can be related to the borders of the basin, where the alpine basement outcrops. In the study area, more than 30 morphotectonic structures could be determined by using exclusively the morphological indices and are presented on the morphotectonic map of Figure 5.

Knowing the tectonic data according to the regional tectonic setting of Kozani area, further analysis of the most significant determined structures was attempted in combination with the available bibliographic references. The major active tectonic structure of the Kozani basin is the NE-SW trending Aliakmonas fault zone (Figure 5 - segments $1 \& 2$ ). It can be observed at the SE part of the project area and comprises a major extensional tectonic feature (Papanastasiou et al., 
1998; Mountrakis et al., 1998; Mountrakis et al., 1999), discernible especially because of its significant effect on the topographic relief. The Aliakmonas fault zone length exceeds $80 \mathrm{~km}$ and constitutes of 3 segments, which can be verified mainly by the drainage pattern. More specifically, the drainage occurs from the footwall of the Aliakmonas fault zone (SE margin of the basin) to the hanging wall (NW margin of the basin) at the lower topographic areas (Goldsworthy \& Jackson, 2000), which seem to be associated to the ends of the fault segments (Figure 2 - areas 4). Two of the three fault segments belong to the project area and correspond to the Rymnio fault and the Servia fault (Figure 5).

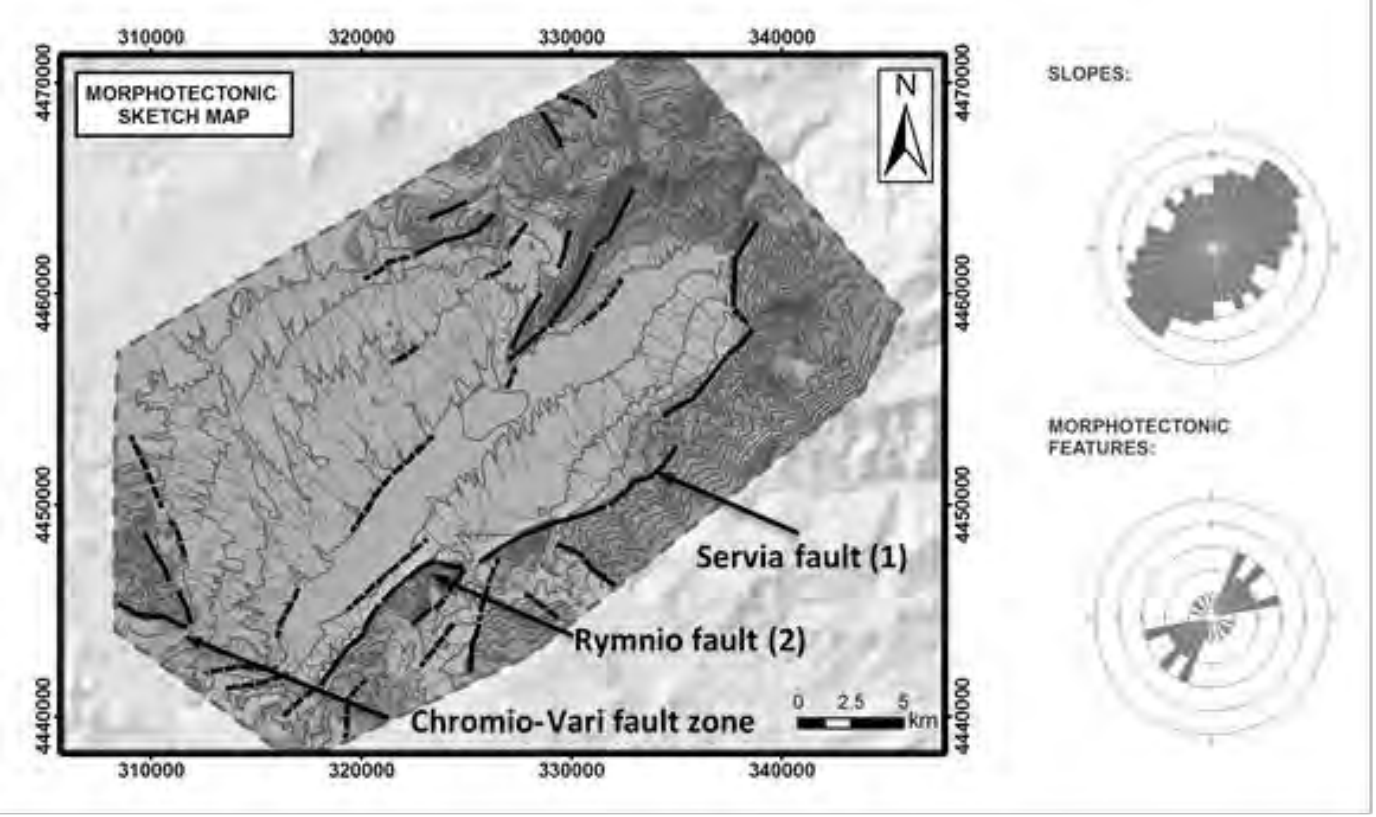

Figure 5-Morphotectonic Sketch Map (GGRS87), presenting the most significant morphotectonic features in Kozani basin (black continuous lines for the distinct - dashed for the probable structures). Dark and light grey colours indicate the alpine basement and the post-alpine sediments respectively. Rose plots (statistical analysis) on the right illustrate the main directions of the slope and the morphotectonic features.

Servia fault (Figure 5; Figure 6) lies in the northern part of the Aliakmonas fault zone and bounds the Kozani basin to the south. It corresponds to one of the most prominent morphotectonic features of the project area, trending NE $-\mathrm{SW}$ and dipping $\sim 60^{\circ}$ towards NW (Papanastasiou et al. 1998). The fault surface is distinct due to the steep slopes that develop in the alpine basement.

Rymnio fault (Figure 5) constitutes the middle part of the Aliakmonas fault zone and consists the Servia fault extension towards SW. It is not as distinct structure as the Servia fault in the field, though it can easily be recognised in the morphotectonic map (Figure 5). The Rymnio fault, dipping $80^{\circ}-85^{\circ}$ near surface and about $30^{\circ}$ deeper (Mountrakis et al, 1998) comprises the main seismogenic structure, which, according to certain researchers, is related to the $13^{\text {th }}$ May 1995 Kozani earthquake (Lekkas et al., 1996; Drakatos et al., 1998). Servia fault was not activated during the earthquake event, possibly because it is geomorphologically separated from the Rymnio fault segment.

Another significant tectonic feature, which is partly observed in the project area, is the ChromioVari fault zone (Figure 5). This feature contributes a WNW-ESE trending, secondary antithetic normal fault, which develops in the hanging wall of the Aliakmonas fault zone. It comprises a 
seismogenic structure that exceeds $15 \mathrm{~km}$ in length, bounds partially the Vourinos ophiolithic complex formations and is covered by the Plio-Pleistocene formations (Mountrakis et al., 1998).

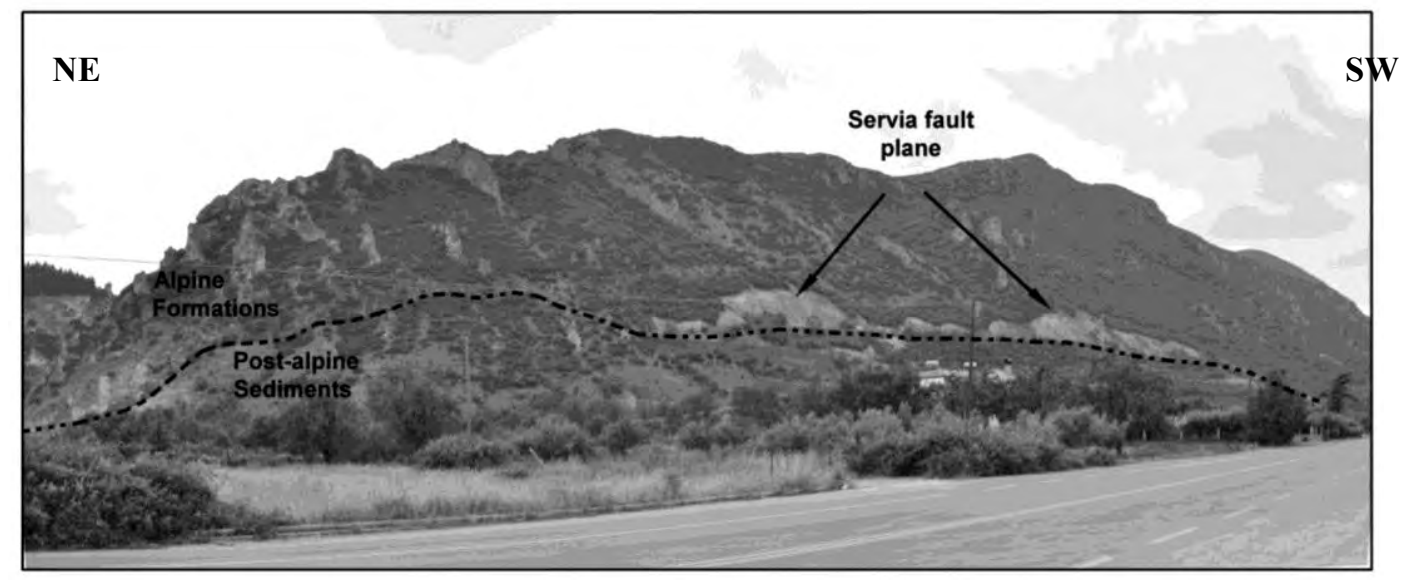

Figure 6 - Panoramic view of Servia fault segment.

On the other hand, the NW part of the project area where the north marginal fault of the basin is considered to be buried under the Plio-Pleistocene sequences, is characterized by smooth topographic relief. The mean morphological slope values, ranging between $1^{\circ}-10^{\circ}$ (Figure 3 ; Figure 4) and the undisturbed parallel drainage pattern (Figure 2 - area 1) indicate the insignificant effect of the active tectonics on that part of the basin, which is characterized by the development of river terraces on the hanging wall of the Aliakmonas fault zone. The study of the Kozani basin by using optical and radar satellite data (Parcharidis et al., 2001) is in accordance with our results, concerning the distribution of the NE-SW trending morphotectonic lineaments.

The morphotectonic features presented on our Morphotectonic Map can be related to the tectonic features that have been already mapped in the wider area of Kozani (Mountrakis et al., 1999).

\section{Discussion}

The paper deals with the compilation of a morphotectonic map for the Kozani basin, based on digital modelling in combination with the regional geological, tectonic and geomorphological setting. Both on local and regional scales, the quantitative characterization of landforms (Morphological slope map - Figure 4) based on DEM analysis (Slope distribution map - Figure 3), contributes to the identification of tectonic lineaments and the characterization of the structural properties of faults on a morphological basis.

The relief, the slope parameters, the drainage pattern asymmetries and the hypsometric high surface roughness support the neotectonic uplift which is accommodated by tectonic features developed primarily in a NE - SW direction, representing the transverse disruptive structures of the E - W oblique opening of Late Pliocene - Quaternary. Moreover, the identified secondary NW - SE trending faults reflect the Oligocene - Miocene extensional stage which corresponds to the last time at which extension was accommodated on arc-parallel structures (Papanikolaou \& Royden, 2007).

The morpho-structural analysis which was operated for the project area gives an accurate scheme of the geometry of the Kozani basin and distinction of the most significant morphotectonic structures, which are presented on our Morphotectonic sketch map (Figure 5) and the following 3D model (Figure 7). 


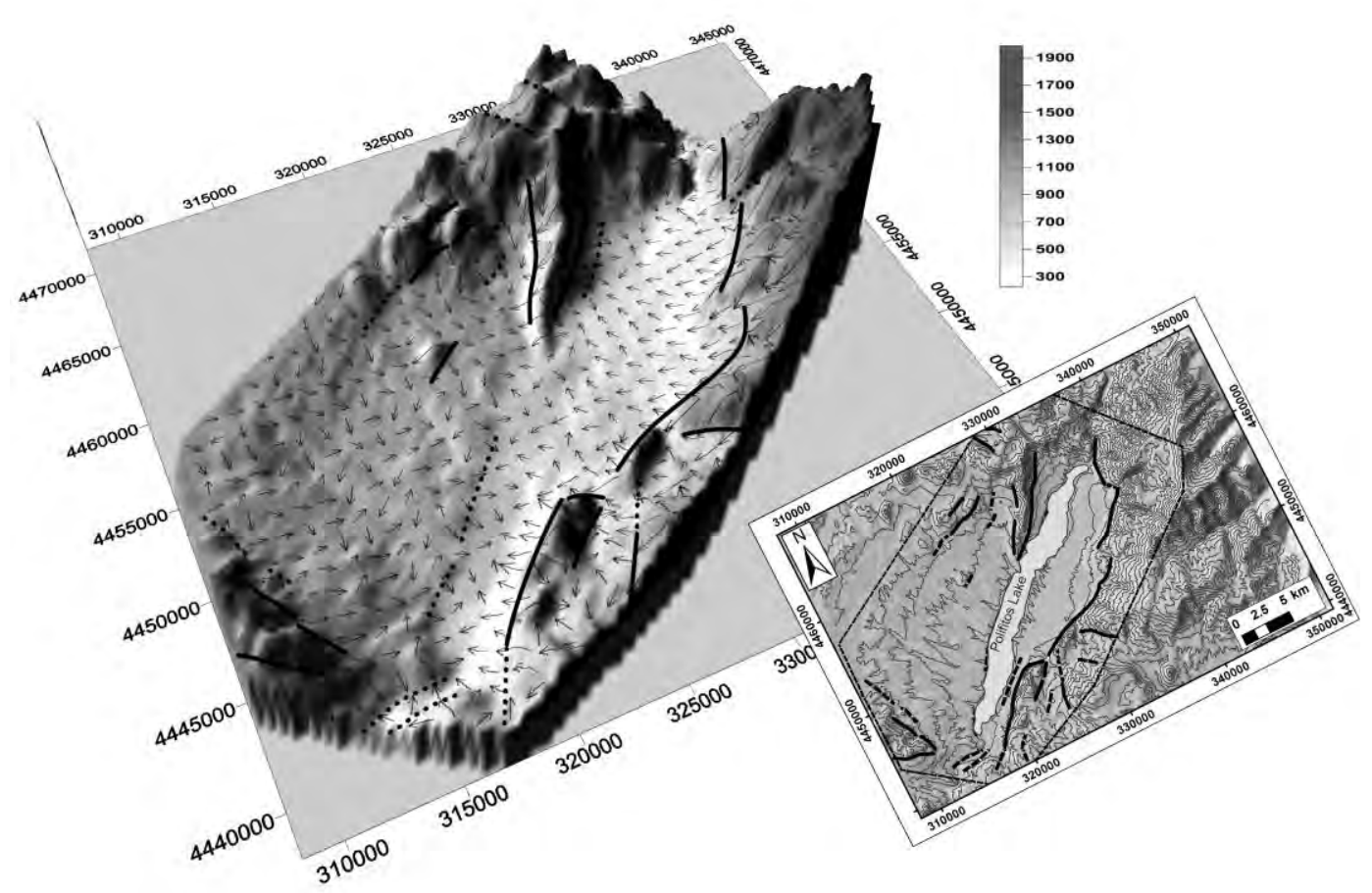

Figure 7 - 3D model of Kozani basin and the relevant Morphotectonic Sketch Map (GGRS87), which illustrate the significant morphotectonic structures of the project area (black continuous lines for the distinct - dashed for the probable structures). View from SSW - (Surfer V. 10 / Rockware).

\section{References}

Burchfiel B.C., Nakov R., Dumurdzanov N., Papanikolaou D., Tzankov T., Serafimovski T., King R.W., Kotzev V., Todosov A. and Nurce B. 2008. Evolution and dynamics of the Cenozoic tectonics of the south Balkan extensional system, Geosphere, 4 (6), 919-938.

Drakatos G., Papanastasiou D., Papadopoulos G., Skafida H. and Stavrakakis G. 1998. Relationship between the 13 May 1995 Kozani-Grevena (NW Greece) earthquake and the Polyphyto artificial lake, Engineering Geology, 51, 65-74.

Goldsworthy M. and Jackson J. 2000. Active normal fault evolution in Greece revealed by geomorphology and drainage patterns, Journal of the Geological Society of London, 157, 967981.

Howard A.D. 1967. Drainage analysis in geological interpretation: A summation, The American Association of Petroleum Geologists Bulletin, 51, 11, 2246-2259.

Lekkas E., Fountoulis I., Lozios S., Kranis Ch. and Adamopoulou E. 1996. Neotectonic Implications of Grevena - Kozani Earthquake (May 13, 1995, W. Macedonia, Greece). International meeting on results of the May 131995 earthquake of West Macedonia: One year after, Kozani, 1996, 76-80.

Mavridis A. and Kelepertzis A. 1993. Geological map of Greece, Knidhi Sheet, Scale 1:50,000, I.G.M.E.

Mountrakis D. 1985. Geology of Greece, University Studio press - Thessaloniki (in Greek). 
Mountrakis D., Kilias A. and Zouros N. 1993. Kinematic analysis and tertiary evolution of the Pindos-Vourinos Ophiolites (Epirus-Western Macedonia, Greece), Bull. Geol. Soc. Greece, Vol. XXVIII/I, 111-124.

Mountrakis D., Pavlides S., Zouros N., Astaras Th. and Chatzipetros A. 1998. Seismic fault geometry and kinematics of the 13 May 1995 Western Macedonia (Greece) earthquake, J. Geodynamics, 26, 2-4, 175-196.

Mountrakis D., Kilias A., Pavlides S., Vavliakis E., Tranos M., Zouros N., Spyropoulos N., Chatzipetros A., Karakostas V., Skordilis M., Gkountromichou Ch. and Thomaidou E. 1999. Neotectonic Map of Greece, Kozani Sheet, Scale 1:100,000. Faculty of Sciences, School of Geology, Aristotle University of Thessaloniki.

Papanastasiou D., Drakatos G., Voulgaris N. and Stavrakakis G. 1998. The May 13, 1995, KozaniGrevena Earthquake, J. Geodynamics, 26, 2-4, 233-244.

Papanikolaou D. 1984. The three metamorphic belts of the Hellenides: a review and a kinematic interpretation, Geological Society of London, Special Publications, 17, 551-561.

Papanikolaou D. 1986. Geology of Greece, National and Kapodistrian University of Athens (in Greek).

Papanikolaou D., Bargathi H., Dabovski C., Dimitriu R., El-Hawat A., Ioane D., Kranis H., Obeidi A., Oaie G., Seghedi A. and Zagorchev I. 2004. The TRANSMED Atlas - Geological and geophysical framework of the Mediterranean and the surrounding areas. A publication of the Mediterranean Consortium for the 32nd International Geological Congress, Springer.

Papanikolaou D. and Royden L. 2007. Disruption of the Hellenic arc: Late Miocene extensional detachment faults and steep Pliocene - Quaternary normal faults - Or what happened at Corinth?, Tectonics, 26, TS5003.

Parcharidis I., Nikolakopoulos K., Serelis K. and Baskoutas I. 2001. Integrated Use of Optical and Radar Satellite Data for Active Faults and Corresponding Displaced Landforms in Kozani Basin. Greece, Geocarto International, 16, 17-23.

Pavlides S. 1985. Neotectonic evolution of Florina - Vegoritis - Ptolemais basin, Phd Thesis, Aristotle University of Thessaloniki.

Pavlides S. and Mountrakis D. 1987. Extensional tectonics of northwestern Macedonia, Greece, since the late Miocene, Journal of Structural Geology, 9, 385-392. 